\title{
AN INVESTIGATION OF DIFFERENT FORMWORK SYSTEM FOR HIGH RISE BUILDING CONSTRUCTION AND FOR DECISION SUPPORT SYSTEM
}

\author{
SHWETA SAGAR ${ }^{1} \&$ VIRENDRA KUMAR PAUL ${ }^{2}$ \\ ${ }^{1,2}$ School of Planning and Architecture, New Delhi, India

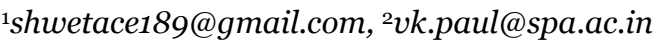

\begin{abstract}
The most important aspect of any successful structural construction is the formwork system. Formwork itself defines as the temporary structure into which the concrete placed to obtain its desired shape and gains its weight to withstand against various loading conditions. This paper focuses on the two parts 1. Identified different formwork systems using in Indian construction industry for high-rise building construction and 2. Explanations of the decision support system for formwork system so that a decision-maker decides or makes the right choice for the selection of formwork system. This study employed a literature review approach (journal paper, research paper, technical articles \& notes, and white paper). The methodology divided into two parts; firstly, the identification of the formwork systems used in the construction industry and secondly, to study a brief about decision support system and for formwork system by which the ease to make a decision support frame for the formwork system selection. This paper reflects the different formwork system typology used in the construction industry for high-rise buildings. The outcome of this paper helps to establish the baseline to develop decision support for the formwork system selection.
\end{abstract}

Keywords: Formwork System, High Rise Building, Decision Support System

\section{Introduction}

\subsection{FORMWORK SYSTEM}

The building construction sector is characterized by an increasing level of mechanization. Formwork is an important constituent of reinforced concrete (RC) structures and reinforced concrete (RC) construction primarily consists of three components; i.e., a. formwork b. reinforcement and c. concrete. Formwork usage has become very extensive in building construction industry, as it offers advantages in terms of quicker execution and better results.

According to Indian Standard, IS: 6461 (Part 5) - 1972, formwork is a complete system of temporary structure built to contain fresh concrete to form it into the required shape and dimensions and to support it until it hardens sufficiently to become self-supporting.

The Indian construction industry has started using some of the excellent latest technologies. Several formwork systems are in use at different places in the world; eventually, the systems, which reasonably economically ease for operation with semi-skilled labor, are more useful in India.

According to the Ministry of Housing and Urban Poverty Alleviation (MoHUPA, 2012), there was a shortage of 18.78 million housing units in urban India. Nearly $95 \%$ of this shortfall was in Economically Weaker Sections (EWS) and Low Income Group (LIG) housing etc. To overcome the shortage of housing units the Ministry of Housing and Urban Poverty Alleviation (MoHUPA) has launched Pradhan Mantri Awas Yojana (PMAY) “Housing for All” (Urban) Mission on 25 $5^{\text {th }}$ June 2015. Based on the estimated shortage of houses, about 2 crore houses are required to be constructed in seven years. To achieve this goal, a multi-pronged approach is necessary including the use of emerging alternate building materials and technologies and especially to formwork systems. A large number of high-rise building construction projects are being undertaken in the residential sector in India (Basu and Jha, 2016).

According to National Institution for Transforming India (NITI) Aayog - Strategy for New India @75, 2018 report, the Ministry of Rural Development (MoRD) and Ministry of Housing and Urban Affairs 
(MoHUA) recently estimates a housing shortage of nearly 3 crore units in rural areas and 1.2crore units in urban areas. Therefore, to achieve the goal of the construction of total 4.2crore housing units in India the formwork system plays an important role for high-rise building construction projects but the problem is still with the construction industry that by which formwork typology the construction of high-rise building needs to be constructed and due to lack of standards and guidelines so the decision cannot be taken into consideration.

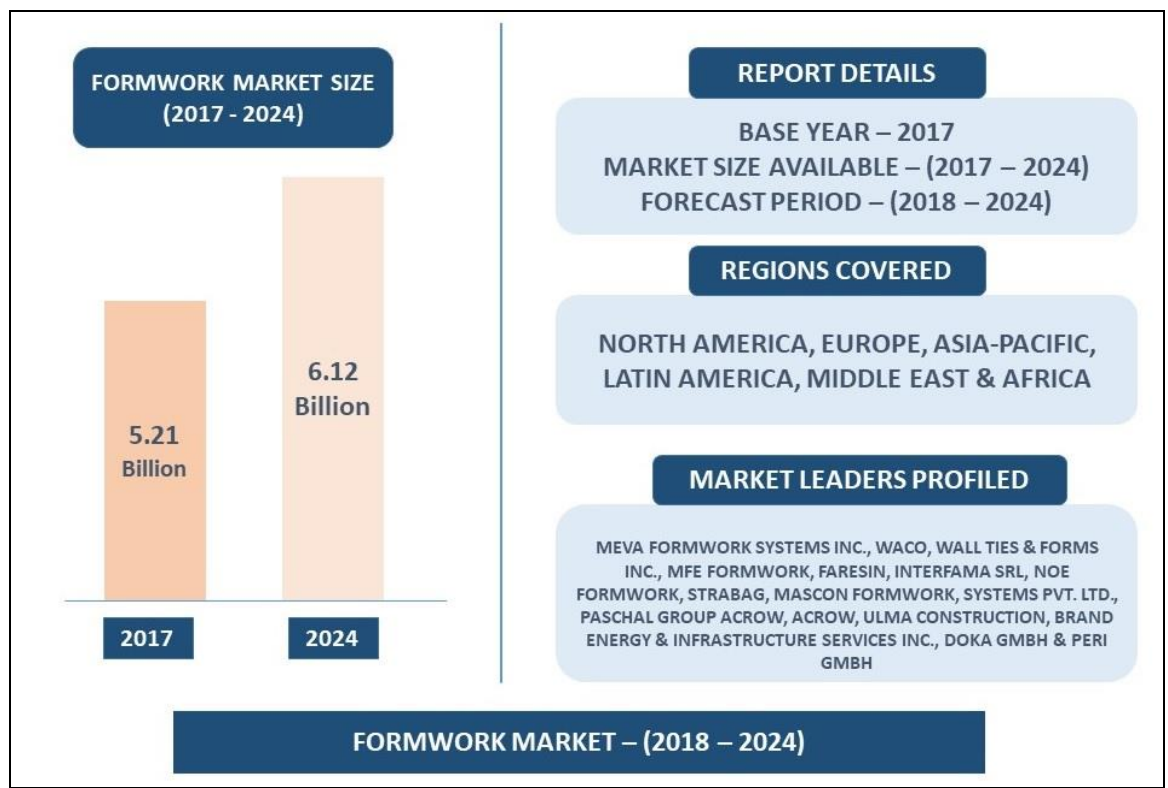

Figure 1, Globally formwork market (2017-2024)

(Source: Formwork Market, Industry Growth, Market Size, Share, Forecast 2018 - 2024)

The various decisions were taken for the selection of formwork system and typically for the identification of the formwork system to be used in the construction industry.

\subsection{DECISION SUPPORT SYSTEM}

The concept of a Decision Support System (DSS), though quite widely used and developed in many research, is by no means well defined. Decision Support Systems (DSS) represent a concept of the role of computers within the decision-making process. It contrasts to decision automation systems that replace humans in repetitive decisions because these decision problems are either too tedious or require very fast reaction time or very high precision.

McCowan and Mohamed (2007) presented that the decision support processes have been widely used to assist managers to determine the most appropriate paths to take. However, despite of all semantic problems it is possible to list several basic characteristics of Decision Support Systems (DSS). Parker and Al-Utabi (1986), Keen and Scott-Morton (1978) and Sprague and Carlson (1982) stated the following characteristics as:

a. DSS assist decision makers in their decision processes in semi-structured \& unstructured tasks;

b. DSS support and enhance rather than replace managerial judgment;

c. DSS improve the effectiveness of decision making rather than its efficiency;

d. DSS attempt to combine the use of models or analytical techniques with traditional data access and retrieval functions; 
e. DSS specifically focus on features which make them easy to use by users who have less knowledge of computer in an interactive mode;

f. DSS emphasize flexibility and adaptability to accommodate changes in the environment and the decision making approach of the user.

\section{Problem Statement And Literature Review}

The poor state of technology (formwork system) opted by the construction sector for high-rise building adversely affects the performance of the complete structure in terms of the poor quality of the structure or building, construction cost is high, the completion time of the project is more, low labor productivity, low-grade raw materials, failure of structure, etc.

According to Building Materials \& Technology Promotion Council (BMTPC - White Paper, 2015), some of the technologies have been developed and are successfully being used in other countries and are trying to implement in the Indian construction industry especially for a high-rise building. Building Materials \& Technology Promotion Council (BMTPC) have identified, evaluated, and promoted sixteen (16) new emerging technologies under PMAY (U), as mentioned in table 1. However, the research work based on the formwork system, and then only formwork system technology needs to be taken into consideration.

Table 1: Emerging construction systems identified by BMTPC

\begin{tabular}{|l|l|l|}
\hline SYSTEM & \multicolumn{1}{|c|}{ TYPE } & \multicolumn{1}{c|}{ TECHNOLOGY } \\
\hline \multirow{3}{*}{$\begin{array}{l}\text { Formwork } \\
\text { System }\end{array}$} & Engineered Formwork System & $\begin{array}{l}\text { Monolithic concrete construction system using aluminum, } \\
\text { plastic-aluminum or composite formwork }\end{array}$ \\
\cline { 3 - 3 } & & Modular tunnel form \\
\cline { 2 - 3 } & Stay-in-place formwork system & Sismo building technology \\
& & Insulating concrete forms \\
\cline { 3 - 3 } & Monolithic insulated concrete system \\
\cline { 3 - 3 } & Structural stay-in-place formwork system (Coffor) \\
& Lost-in-place formwork system (Plaswall panel system) \\
& Plasmolite wall panels \\
\hline
\end{tabular}

Formwork represents a significant part of any concrete construction project and accounts for 40-60\% of the cost of the concrete skeleton and about 10\% of the total construction cost (Hanna, et al., 1992; Shin, et al., 2008; Shin, et al., 2012; Shin, Y., 2011; Eder, et al., 2016).

Selection of an appropriate formwork system is an extremely crucial and complex factor for the successful completion of any residential (high-rise building) construction project (Basu and Jha, 2016; Eder, et. al., 2016). Selection of the optimum formwork system requires years of experience in formwork analysis and design but before selection of the formwork system for high-rise building need to investigate the formwork system typologies.

An extensive study has been carried out for the decision support system and formwork system to overcome the situation of choosing the right formwork system for high-rise building construction. As decision support system itself is complex and perplexed, therefore, many researchers have developed the decision support system as in terms of using the optimization methods/tool or by using the multicriteria decision-making method (MCDM) between two to three formwork systems and choose for the best and especially conventional formwork system with the mechanized formwork system. None of the studies has the formwork system typologies based classification for high-rise building construction. Hence, the need of a decision support system is crucial and essential for the formwork system for enduring decisions. 
According to Sprague \& Watson, (1996) presented a conceptual model are critical to understand the newly complex DSS. The author categorized the DSS into interactive computer based system that helps to solve structured, semi - structured, and unstructured model/framework for decision-making.

Randall E. Louw (2002), the author explain \& presented the detailed about DSS history, category. The author introduced the uses \& requirements of information at different managerial level because DSS helps to improve management control by considering primary task as -

1. Allocation of resources to specific activities.

2. The expenditure of resources and the expected achievement goals and objectives will help to prepare the budget.

3. Observation of results achieved in return for resources used.

4. Evaluation of results

5. Make the modification in above for tasks

At last, the author concluded that DSS could be extremely beneficial to any organization's overall performance. DSS can also be the cause of great confusion, misperception \& even inaccurate analysis as these systems are not designed to eliminate bad decision.

Safa, H. et. al. (2016), the authors contributes to the development of unavailable model for facilitating \& validating formwork decision, which based on the advantages, and disadvantages of the different forming systems. The authors identifies 9 types of forming method \& system i.e., stick-built, split forms, molds (for architectural elements), paving \& towers (horizontal \& vertical), aluminum frame \& panel section, modular \& quick connect, insulating concrete forms (ICF), reusable wood section (elevator core), but the focused only on 5 classification. The author's model based on the Hanna upgrade theory, which was taken by Construction Industry Institute (CII). It is knowledge expert DSS. The author compares the pros and cons to identify the decision for formwork. The author concluded that to assist decision makers, the decision model based on the advantages \& disadvantages of the latest formwork systems versus old/traditional formwork system and suggested the latest/modular system, the best choice or decision in application with the high amount of repetitions.

Shin, Y., et. al. (2012), the authors proposed a formwork selection model based on boosted decision trees to assist the practitioner's decision-making; the selection has depended mainly on the subjective and intuitive opinions of practitioners with restricted experience. The author uses three different model methods as ANN, DT, BDT to select the best decision for the formwork method such as wood form, con-panel, aluminum forms, table form, sky-deck for tall buildings. The case studies are taken in to consideration, which was restricted to Korea only. For data collection, the authors took data from 15 major general contractors for 75 tall building construction projects in large cities of Korea. The formwork selection model based on BDT tested by applying it to real cases of tall building projects. Thus the results shows from the five-folds of formwork and cross validation with 20-21 different test datasets using ANN, DT, BDT. The result of the three different models for either formwork selection model showed that the BDT model is more accurate that the ANN model or the DT model. Lastly, the authors proposed a formwork selection model based on the BDT to assist practitioners' decisionmaking in selecting a formwork method suitable for construction site condition in tall building construction projects.

Hanna et al. (1992) proposed using an expert system for the selection of vertical and horizontal formwork systems. The knowledge base required by the expert system was built based on literature and information gathered from North American experts. The expert system was tested on hypothetical projects. 


\section{Research Methodology}

A simple research methodology was implemented which was divided into two phases. In phase - I of research methodology focus on the identification of the formwork system and its typology used for high-rise building construction and in phase - II of research methodology focuses on the study of decision support system for formwork system.

\section{Scope And Limitation}

The scope of this study is limited to the identification of the formwork system and its typology. Formwork system typology is further classified as repetitive formwork system typology; non-repetitive formwork system typology. These classifications will further classify based on the factor for the formwork system selection.

An introduction of decision support system (DSS) taken into consideration for the formwork system and it is taken in the form of DSS definitions, DSS for the different formwork system. However, formwork system typology is not only the responsible parameter for making a decision support system; the factors responsible for formwork system selection are not identified in this study and can be taken for further research.

\section{Research Finding And Discussion}

To identify the formwork typologies, the total 59 (International \& Indian journal, research papers, and technical article \& notes) were investigated and presented in the below table 2.

Table 2: The number of identified Formwork Typology in the respective years (Source: Author)

\begin{tabular}{|c|c|c|c|}
\hline Sr. No. & Year & Formwork Typology & $\begin{array}{c}\text { No of Formwork } \\
\text { Typology identified w.r.t } \\
\text { no. of years } \\
\end{array}$ \\
\hline 1. & 2016 & Stick-built Formwork & 1 \\
\hline 2. & $2013,2016,2017$ & Modular Formwork & 4 \\
\hline 3. & 2005, 2016, 2018 & Prefabricated Formwork & 3 \\
\hline 4. & 2016,2019 & Insulating Concrete Formwork & 2 \\
\hline 5. & 2016 & 3D Printing Formwork & 1 \\
\hline 6. & $\begin{array}{l}2005,2011,2012,2013,2014, \\
2015,2016,2017,2018,2019\end{array}$ & Aluminum Formwork & 21 \\
\hline 7. & 2011, 2012 & Sky-deck Formwork & 3 \\
\hline 8. & $\begin{array}{l}\text { 1992, 2000, 2005, 2011, 2012, } \\
2013,2014,2015,2016,2017, \\
2018,2019\end{array}$ & Wood/Timber Formwork & 31 \\
\hline 9. & 2016,2018 & Modern Formwork & 3 \\
\hline 10. & $\begin{array}{l}2005,2013,2014,2015,2016, \\
2017\end{array}$ & Steel Formwork & 13 \\
\hline 11. & 2013, 2014, 2015, 2016, 2017 & Plastic Formwork & 7 \\
\hline 12. & 2016,2017 & Traditional Formwork & 3 \\
\hline 13. & 2017 & Horizontal Formwork & 1 \\
\hline 14. & 2005,2012 & Vertical Formwork & 2 \\
\hline 15 . & $\begin{array}{l}2005,2011,2012,2017,2018, \\
2019\end{array}$ & Table/Flying Formwork & 8 \\
\hline
\end{tabular}




\begin{tabular}{|l|l|l|c|}
\hline 16. & $2010,2013,2016$ & Climbing Formwork & 3 \\
\hline 17. & 2015,2017 & Tunnel Formwork & 3 \\
\hline 18. & $1992,2015,2019$ & Jump Formwork & 6 \\
\hline 19. & $\begin{array}{l}1992,2005,2013,2015,2018, \\
2019\end{array}$ & Slip Formwork & 6 \\
\hline 20. & $2009,2011,2016$ & Fabric Formwork & 1 \\
\hline 21. & 2016 & Coffer Formwork & 1 \\
\hline 22. & 2011 & Flexible Formwork & 2 \\
\hline 23. & 2017 & Controlled Formwork & 1 \\
\hline 24. & 2015,2016 & Pneumatic Formwork & 1 \\
\hline 25. & 2018 & Hanging Formwork & 3 \\
\hline 26. & 1992 & Self-raising Formwork & 1 \\
\hline 27. & $1992,2004,2005$ & Ganged Formwork & 4 \\
\hline 28. & 1992 & Column/Wall Formwork & \\
\hline 29. & $1994,1999,2011,2015$ & Slab Formwork & \\
\hline \multicolumn{2}{|c|}{ Noted: There is the repetition of years, so taken as the single year. } \\
\hline
\end{tabular}

According to table 2; the highest number of formwork typology was identified as 31 and the lowest number as 1 in the given respective years. The highest number is of wood/timber formwork system, as the conventional formwork system was an ancient type of formwork system were used in the construction of any structure and the lowest number 1 is for few formwork systems and they are not commonly used for the construction of high-rise building construction. Further the formwork typologies were narrow down to the limited number and then to the repetitive and non-repetitive typology as shown in figure 2 and figure 3 .

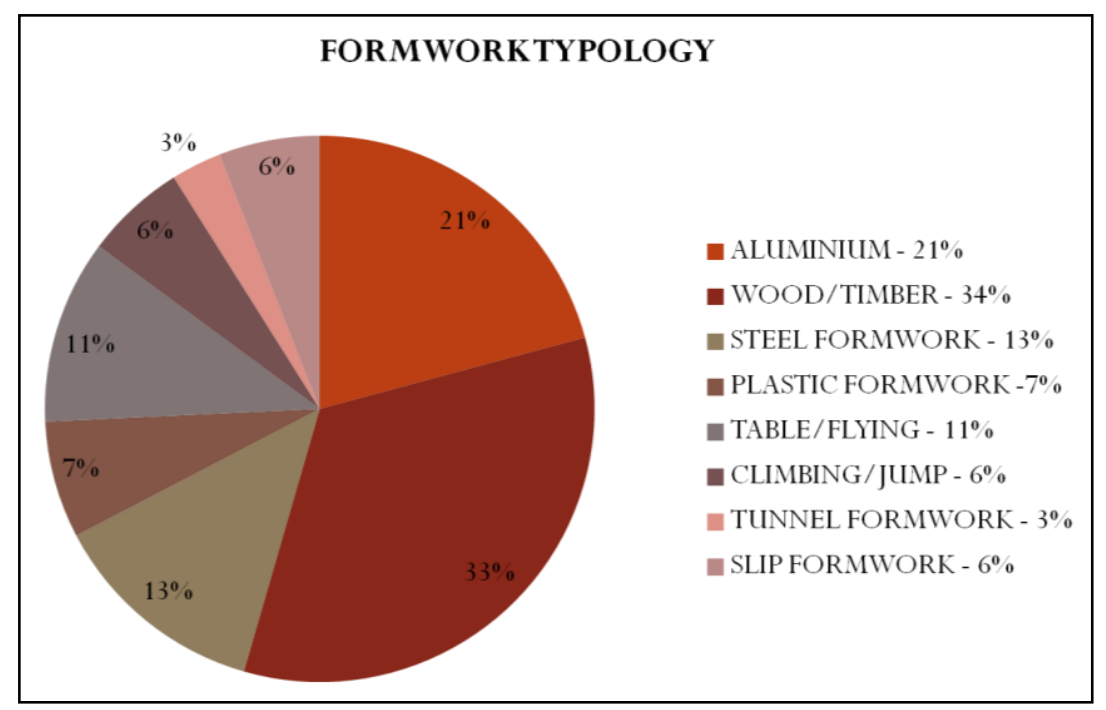

Figure 2, Identified Formwork Typology which are highly used in construction 


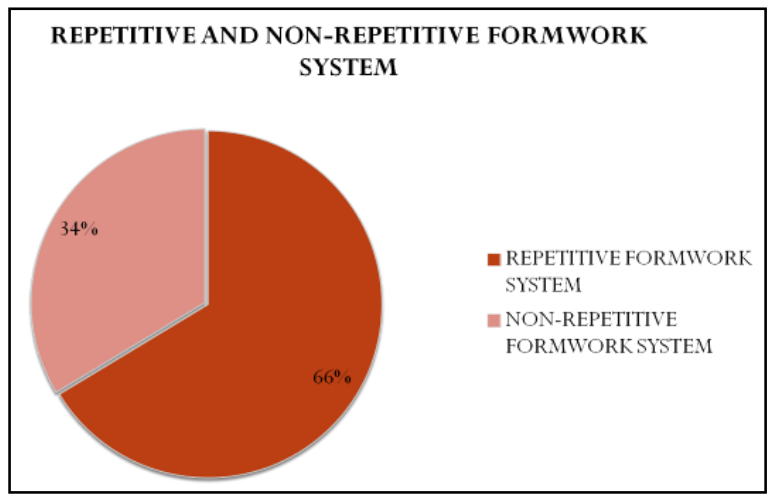

Figure 3, Categorized into repetitive and non-repetitive formwork system

\section{Conclusion}

With the increasing pace of construction industry development in the country, mostly high-rise building is being constructed globally. Nevertheless, according to table 2, it was concluded that the conventional formwork system is more commonly used for the construction of high-rise buildings. The choice and arrangement of utilizing formwork is highly depended on individual site/project environment and several factors.

From table 2, the eight-formwork typology needs to look forward for this research. In figure 2, the selected or identified formwork typology as it is shown in the format of pie chart. In figure 3, again it is classified as repetitive and non-repetitive formwork system. The repetitive formwork systems are that type of formwork system, which can be used repeatedly with some number of extents for construction, i.e., nature of repeating. The non-repetitive formwork systems are that type of formwork system, which cannot be used repeatedly for construction, i.e., nature of non-repeating.

However, from figure 2, concluded that the wood/timber formwork system cannot be used repeatedly, thus considering in non-repetitive formwork system as shown in figure 3.

Another valid reason found from the literature review, there is lack of the system or framework that directly makes the right selection of formwork for the right type of building typology to be constructed which will fulfill the need of the stakeholders to make the right decision for selecting right formwork and right building typology. Mostly noticed from literature review, the contractors provide those formwork typologies, which are available with them.

Decision Support System, plays an important role in making the decision in any organization. Focused on the decision support system for formwork, which mainly consists of two or three formwork typology or took as general for the decision to be made by few method/tool such as ANN, BT, etc.

However, around 5.03 percent of India's population is still houseless (2001 Census) (including 4.03 percent institutional population). The three major bottlenecks in the construction of high-rise buildings are: (a) lack of knowhow on making disaster-resistant housing, (b) lack of expertise for effectively using local material in house construction, and (c) inadequate finances. Other bottlenecks are (d) lack of knowledge and experience in the latest formwork system technologies, (e) shortage of skilled workforce, (f) high machinery cost, (g) lack of training sessions, etc. The State Governments in association with the Central Government have undertaken several high-rise building projects to provide houses to the needy because the selection of an appropriate formwork system is an extremely crucial factor for the successful completion of any high-rise building construction project. 


\section{References}

Annual report of Building Materials \& Technology Promotion Council (BMTPC), 2015

Basu, R., and Jha K. N: 2016, An AHP Based Model for the Selection of Horizontal Formwork Systems in Indian Residential Construction, International Journal of Structural and Civil Engineering Research Vol. 5, No. 2., pp: 80-86

Hanna, A.S., Willenbrock, J.H. and Victor, E.S: 1992, Knowledge acquisition and development for formwork selection system, Journal of Construction Engineering \& Management, Vol. 118, pp: 179-198

Indian Standard IS: 6461 (Part 5) - 1972, Glossary of terms related to cement concrete: Part 5 formwork for concrete.

Keen, P.G.W \& Scott Morton, M.S., 1978, Decision support systems - an organizational perspective, Addison-Wesley series on Decision support

NITI AAYOG report "Strategy for New India @ 75”, 2018

Parker, B.J. \& Al-Utabi, G.A., 1986, Decision support systems: the reality that seems to be hard to accept?, Omega international journal of management science, Vol. 14(2)

Randall, E. Louw, 2002, Decision support system, Information System Analysis 488

Report on the Technical Group on Urban Housing Shortag (TG-12) (2012-2017), Ministry of Housing \& Urban Poverty Alleviation (MoHUPA)

Safa, M., Sean, R., Carl, T.H., Goodrum, M.P., Carlos, H.C., 2016, A decision-making method for choosing concrete forming systems, International Journal of Construction Management- Taylor \& Francis Group, pp: 1-12

Shin Y.,2011, Formwork system selection model for tall building construction using the Adaboost algorithm. J Korea Inst Build Construction, Vol. 11(5):523-529

Shin, Y., Kim, T., Cho, H., Kang, K.I., 2012, A formwork method selection model based on boosted decision trees in tall building construction, Automation in Construction - Elsevier, ISBN: 0926-5805, pp: 47-54

Shin Y, Kim DW, Yang SW, Cho HH, Kang KI., 2008, Decision support model using the AdaBoost algorithm to select formwork systems in high-rise building construction, In: Proceedings of the 25th international symposium on automation and robotics in construction, Vilnius. Gediminas Technical University Publishing House "Technika", Vilnius, Lithuania, pp 644-649

Sprague, R.H. \& Carlson, C. Eds., 1982, Building effective decision support systems, Prentice Hall, Inc.

Sprague, R.H. and Watson, H.J., 1996, Decision Support for Management. Upper Saddle River: Prentice-Hall. 